\title{
The distribution and variability of heavy metals in a mountainous fir forest ecosystem in two hydrological years
}

\author{
Michopoulos P. ${ }^{*}$, Bourletsikas A. ${ }^{1}$, Kaoukis K. ${ }^{1}$, Daskalakou E. ${ }^{1}$, Karetsos G. ${ }^{1}$, Kostakis M. ${ }^{2}$, Thomaidis N.S. ${ }^{2}$, Pasias I.N. ${ }^{2}$, Kaberi H. ${ }^{3}$ \\ and Iliakis $\mathrm{S}^{3}$ \\ ${ }^{1}$ H.A.O. DEMETER-Institute of Mediterranean Forest Ecosystems, Terma Alkmanos, Athens 115 28, Greece \\ 2Laboratory of Analytical Chemistry, Department of Chemistry, National and Kapodistrian University of Athens, Athens 157 71, Greece \\ ${ }^{3}$ Hellenic Centre for Marine Research, Institute of Oceanography, 46.7 km Athinon-Souniou ave., 19013 Anavyssos, Greece \\ Received: 01/11/2017, Accepted: 06/01/2018, Available online: 02/04/2018 \\ *to whom all correspondence should be addressed: e-mail: mipa@fria.gr
}

\section{Abstract}

The concentrations (for two hydrological years) of the heavy metals $\mathrm{As}, \mathrm{Cd}, \mathrm{Cr}, \mathrm{Ni}$ and $\mathrm{Pb}$ as well as the isotopic ${ }^{206} \mathrm{~Pb} /{ }^{207} \mathrm{~Pb}$ composition in soil layers were studied in a remote mountainous Bulgarian fir (Abies borisii regis) forest in central Greece. The concentrations of metals in the hydrological cycle (bulk deposition and throughfall) were lower than the respective ones in the past in Europe, especially for $\mathrm{Pb}$. In the litterfall consisting of mosses, lichens, insect frass and pollen the concentrations of all heavy metals were found far higher than those in the needle litterfall. An evidence of dry deposition was that all metals had higher concentrations in older needles than the young ones with the exception of $\mathrm{Ni}$. $\mathrm{Ni}$ also had the highest concentration in the trunk wood, whereas all the other metals had a very low one. It is highly probable that Ni has an internal cycle within the fir trees. In all compartments of the standing trees the order of concentrations was $\mathrm{Ni}>\mathrm{Pb}>\mathrm{Cr}>\mathrm{Cd}>\mathrm{As}$. The concentrations of metals in the ground vegetation were low with the exception of $\mathrm{Cd}, \mathrm{Cr}$ and $\mathrm{Ni}$ in ferns. The concentrations of metals in the $\mathrm{FH}$ horizon and mineral soil followed the order $\mathrm{Cr}>\mathrm{Ni}>\mathrm{Pb}>\mathrm{As}>\mathrm{Cd}$, whereas in the $\mathrm{L}$ layer $\mathrm{Ni}$ had the highest value. Despite the remoteness of the fir forest, the percentages of anthropogenic $\mathrm{Pb}$ in the soil reached an appreciable $41 \%$ in the $\mathrm{FH}$ horizon and lowered to $2 \%$ in the 20-40 cm layers.

Keywords: heavy metals-Bulgarian fir-concentrations- $\mathrm{Pb}$ isotopes

\section{Introduction}

Environmental pollution by heavy metals results from many sources including industrial activities, power generation, transport (especially in urban environment) and agriculture (Tipping et al., 2006). Forest vegetation close to such sources of pollution can be heavily affected. It is quite logical that a lot of studies have focused on the effects of heavy metals on forests located nearby of such sources (Pietrzykowski et al., 2014; Bache et al., 1992; Michopoulos et al., 2005; Martin et al., 1982; Mingorance et al., 2007; Kapusta et al., 2003). However, to a lesser extent, even remote forests can also be affected. This is due to the atmosphere, which serves as a transport means in long distances (Steiness and Friedland, 2005). Moreover, heavy metals tend to accumulate in soils in time. Therefore, even in small quantities they can have adverse effects on forest functions after a long time. This is the reason that research has been carried out in remote forests. Conifers have a particular capacity to trap the dry deposition of heavy metals due to their vast foliage surface. Foliage drops as litterfall which decomposes, and heavy metals end up in soils or taken up by plants just like nutrients. One of the first studies was that of Heinrichs and Mayer, (1977). The authors dealt with the distribution and cycling of $\mathrm{Mn}$, $\mathrm{Co}, \mathrm{Cr}, \mathrm{Cu}, \mathrm{Ni}, \mathrm{Pb}, \mathrm{Sb}, \mathrm{Sr}, \mathrm{V}, \mathrm{Zn}, \mathrm{Bi}, \mathrm{Cd}, \mathrm{Hg}$ and $\mathrm{Ti}$ in beech and spruce forests in central Germany. Van Hook et al., (1977) worked with the distribution of $\mathrm{Cd}, \mathrm{Pb}$ and $\mathrm{Zn}$ in a mixed deciduous forest in eastern Tennessee (USA). Zöttl, (1985) reviewed the distribution and cycling of $\mathrm{Mn}, \mathrm{Cu}, \mathrm{Cd}$, $\mathrm{Pb}$ and $\mathrm{Be}$ in the Black Forest in Norway spruce stands in Germany. Huang et al., (2011) studied the cycling of Cd, Zn, $\mathrm{Cu}$ and $\mathrm{Cr}$ in forest stands of Norway spruce in German mountains. Due to the widespread emission of $\mathrm{Pb}$ in the past, many studies focused on this element. Friedland and Johnson, (1985) studied the distribution of $\mathrm{Pb}$ in forests of red spruce, balsam fir and white birch in in the southeastern USA, Turner et al., (1985) in forests of pitch pines and white and black oaks in New Jersey, Watmough and Dillon, (2007) in forests of white pine, eastern hemlock, red oak and red maple in central Ontario, USA.

The aim of this work was to investigate the concentrations of $\mathrm{As}, \mathrm{Cd}, \mathrm{Cr}, \mathrm{Ni}$ and $\mathrm{Pb}$ in a remote mountainous Bulgarian fir (Abies borisii regis Mattf.) forest in central Greece in as many forest compartments as possible. In addition, the isotopic $\mathrm{Pb}$ composition in the soil profiles was assessed to find the percentage of the anthropogenic contribution to $\mathrm{Pb}$ stocks in the soil. The Bulgarian fir, a hybrid between silver fir (Abies alba Mill) and Greek fir (Abies cephalonica Loudon) occupies the fir zone of central and northern Greece. These three species are hard to distinguish and occupy a significant area in the central and southern 
Europe. The Abies species are very sensitive to environmental stress. The silver fir was the first species to present symptoms of forest decline in the past in southern Germany (Krauss et al., 1986). In the last decades, the mortality rate of these fir species was very high (Certini et al., 2000; Raftoyannis et al., 2008; Markalas, 1992). So far, there have been two works on heavy metal distribution on Abies species by Gandois et al., (2010) and Gandois and Probst, (2012). The authors examined the distribution of $\mathrm{Zn}, \mathrm{Ni}, \mathrm{Cu} \mathrm{Pb}$ and $\mathrm{Cd}$ in a silver fir ecosystem without including litterfall. There has also been one work on the limits of decomposition rates set on silver fir litterfall by concentrations of heavy metals in south Italy (Berg et al., 2003). In conclusion, the information for such valuable species as Abies is very limited. Furthermore, most studies on heavy metals in forests have focused on $\mathrm{Pb}$ and $\mathrm{Cd}$. The present work has also included $\mathrm{As}, \mathrm{Cr}$ and $\mathrm{Ni}$. As the fir forest under consideration is situated on a good quality site, it can serve as reference to future heavy metals biogeochemical studies.

\section{Materials and Methods}

\subsection{Study area}

The experimental plot is situated in the mountain Timfristos in central Greece, at an altitude of $1170 \mathrm{~m}$. It has an area of 0.27 ha and is enclosed in a catchment of a total area of $147 \mathrm{ha}$. The average annual rain height is $1530 \mathrm{~mm}$. The vegetation cover consists of an even aged Bulgarian fir (Abies borisii regis M.) stand in good health having an average age of 100 years approximately. The ground vegetation consists mainly of ferns (Pteridium aquilinum L.), shrubs (Rubus hirtus W. \& K.), herbs (Sanicula europaea L., Geranium lucidum L., Geranium rotundifolium L., Luzula forsteri Sm.) and plants from the family Gramineae such as Melica uniflora R. and Brachypodium sylvaticum $\mathrm{H}$.

The soil was developed on sandy flysch, it is deep and classified as Humic Alisols (FAO, 1988).

\subsection{Experimental set up and sampling}

\subsubsection{Bulk and throughfall deposition collection}

In the year 1997, bulk and throughfall deposition collectors were installed in the plot to monitor the quantity and chemistry of precipitation. Bulk deposition was collected with three collectors placed in a forest opening very close to the stand. For throughfall measurements, 30 collectors were placed randomly under the tree canopies in the plot. Bulk and throughfall deposition collectors were identical and each of them consisted of an $18 \mathrm{~cm}$ diameter polyethylene funnel attached through a one-meter long hose to a five litter polyethylene bottle. Litter was blocked from entering the funnels with a plug of tulle. The assembly was enclosed vertically in a PVC drainage pipe, dug firmly into the soil to keep the collecting bottle underground so as to exclude light from the water samples. The volume of bulk and throughfall deposition for each collector was measured in the field with a graduated cylinder and a pooled sample was brought back to the laboratory for analysis.
Deposition collection was done weekly, and water volume was measured immediately. Afterwards, samples were placed in plastic bottles and stored at $0{ }^{\circ} \mathrm{C}$ in a refrigerator. After each sample collection, all collectors and funnels were washed thoroughly with deionized water. From the middle of November till the beginning of April funnels and bottles were replaced with plastic bags to collect snow.

Both bulk deposition and throughfall formed a pooled sample per month by mixing the weekly samples according to their volume.

All water samples passed through a $0.45 \mu \mathrm{m}$ filter prior to analysis.

\subsubsection{Soil samples collection}

The soil samples collection was carried out by means of systematic sampling. Inside the plot, along three lines distancing $25 \mathrm{~m}$ from each other six soil pits were excavated. Each pit was $5 \mathrm{~m}$ away from each other. From each soil pit, the samples collected were the $L$ and the $F H$ horizon by means of a frame $15 \times 15 \mathrm{~cm}$ and mineral soil layers from the depths $0-10 \mathrm{~cm}, 10-20 \mathrm{~cm}, 20-40 \mathrm{~cm}$ and $40-80 \mathrm{~cm}$. There was mixture of six samples of equal volume per horizon and soil depth to have three pooled samples per horizon and depth. The samples of the $\mathrm{L}$ horizon at their initial conditions and those of the $\mathrm{FH}$ horizon and mineral layers after sieving were pulverized in a ball mill for the purpose of total heavy metal analysis.

\subsubsection{Litterfall collection}

For litterfall collection, 10 littertraps in the form of cylindrical plastic buckets, each having a collecting area of $0.242 \mathrm{~m}^{2}$, were placed systematically along a line in the plot, approximately $0.50 \mathrm{~m}$ above ground at a distance of $10 \mathrm{~m}$ from each other. The bottom of each bucket was perforated so that rain or snowmelt water could drain out. A plastic net was put at the bottom of the littertraps to avoid loss of small material. Collection of litterfall was done monthly or for longer periods, depending on the accessibility of the area due to snow. A composite sample was formed and transported to the laboratory for analysis. Needles, twigs, lichens, mosses, insect frass and pollen were separated and dried at $80^{\circ} \mathrm{C}$ for 48 hours.

\subsubsection{Sampling years}

Bulk deposition, throughfall, soil and litterfall were collected for two hydrological years (2012-2013 and 20132014). Each hydrological year started on the 1st of October and ended on the $30^{\text {th }}$ of September.

\subsubsection{Ground vegetation collection}

The ground vegetation was collected in a systematic way by means of a frame having an area of $0.544 \mathrm{~m}^{2}$. The collection took place in September of 2009. The categories collected were herbs, ferns and grasses. Each category formed a pooled sample, which included both leaves and stems.

All the categories of ground vegetation were dried at $80{ }^{\circ} \mathrm{C}$ for 48 hours. 


\subsubsection{Needles collection}

Conifers retain needles for a few years. For this reason it is advisable, for nutrition or pollution studies, to sample needles of the last year growth (current), second and older years. In our study, needle samples of current, second year and older needles were collected every two years in winter (dormant period) from the upper part of the crown from five dominant trees and formed a pooled sample. The collection always took place from the same trees. The three fractions of needles were dried at $80^{\circ} \mathrm{C}$ for 48 hours.

\subsubsection{Bark and trunk wood collection}

Samples of bark and wood were taken from the same trees from which foliage was collected and formed pooled samples.

\subsection{Chemical analysis}

The soil $\mathrm{pH}$ was determined by a glass electrode in a mixture of soil and water at a ratio of 1:5 per volume. The soil texture was measured by the pipette method. The organic $\mathrm{C}$ was determined by a $\mathrm{C}$ analyzer.

Exchangeable cations in soils were extracted with a $0.1 \mathrm{M}$ $\mathrm{BaCl}_{2}$ solution and cation exchange capacity (C.E.C.) was calculated by adding the calculated exchangeable cations.

Concentrations of metals in $\mathrm{BaCl}_{2}$ extracts, deposition and soil solution were determined with an ICP-MS instrument (Thermo iCAP Qc). Soil and plant tissues (needles, litterfall, wood, bark and ground vegetation) were digested in a microwave oven with $\mathrm{HF}$ and aqua regia at a temperature range of $160-170{ }^{\circ} \mathrm{C}$ for $20 \mathrm{~min}$. Likewise, the metal concentrations were measured with the same ICP-MS instrument.

The $\mathrm{Pb}$ isotope ratios were determined with an $\mathrm{X}$ series 2 ICP-MS (Thermo).

The quality assurance of the metal analysis was checked with the use of sediment samples (TAQC!-River Sediment,

Table 1. Concentrations ( $\mu \mathrm{g} \mathrm{L}^{-1}$ ) of heavy metals in bulk and throughfall deposition in the two hydrological years

\begin{tabular}{|c|c|c|c|c|c|}
\hline \multicolumn{6}{|c|}{ 2012-2013 } \\
\hline \multicolumn{6}{|c|}{ Bulk } \\
\hline & As & Cd & $\mathrm{Cr}$ & $\mathrm{Ni}$ & $\mathrm{Pb}$ \\
\hline Mean & 0.075 & 0.024 & 0.041 & 0.358 & 0.163 \\
\hline Range & $(0.027-0.357)$ & $(0.05-0.101)$ & $(0.001-0.174)$ & $(0.122-1.34)$ & $(0.039-0.384)$ \\
\hline \multicolumn{6}{|c|}{ Throughfall } \\
\hline & As & $\mathrm{Cd}$ & $\mathrm{Cr}$ & $\mathbf{N i}$ & $\mathrm{Pb}$ \\
\hline Mean & 0.108 & 0.016 & 0.118 & 0.683 & 0.301 \\
\hline Range & $(0.041-1.01)$ & $(0.09-0.069)$ & $(0.055-0.383)$ & $(0.228-4.58)$ & $(0.107-1.42)$ \\
\hline \multicolumn{6}{|c|}{$2013-2014$} \\
\hline \multicolumn{6}{|c|}{ Bulk } \\
\hline & As & Cd & $\mathrm{Cr}$ & $\mathrm{Ni}$ & $\mathrm{Pb}$ \\
\hline Mean & 0.109 & 0.069 & 0.307 & 0.669 & 0.412 \\
\hline Range & $(0.054-0.192)$ & $(0.021-0.937)$ & $(0.080-1.54)$ & $(0.368-2.14)$ & $(0.210-0.861)$ \\
\hline \multicolumn{6}{|c|}{ Throughfall } \\
\hline & As & $\mathrm{Cd}$ & $\mathrm{Cr}$ & $\mathbf{N i}$ & $\mathrm{Pb}$ \\
\hline Mean & 0.119 & 0.025 & 1.47 & 0.789 & 0.925 \\
\hline Range & $(0.065-0.237)$ & $(0.001-0.063)$ & $(0.010-5.19)$ & $(0.430-1.34)$ & $(0.278-3.65)$ \\
\hline
\end{tabular}

training on Analytical Control-Water Framework directive) and that of the isotope with the use of certified reference material (BCR-2 (United States Geological Survey).

\subsection{Calculations}

\subsubsection{Statistics}

The coefficients of variation (\%) were calculated as the percentages of the standard deviations over the means for the heavy metal concentrations and the isotopic ratios in soils.

\subsubsection{Pb isotopic ratios}

The percentage of anthropogenic $\mathrm{Pb}$ was calculated according to the following equation (Emanuel and Erel, 2002):

Percentage of anthropogenic $\mathrm{Pb}=100 \times\left[\left({ }^{206} \mathrm{~Pb} /{ }^{207} \mathrm{~Pb}\right.\right.$ geogenic- ${ }^{206} \mathrm{~Pb} /{ }^{207} \mathrm{~Pb}$ soil sample $) /\left({ }^{206} \mathrm{~Pb} /{ }^{207} \mathrm{~Pb}\right.$ geogenic${ }^{206} \mathrm{~Pb} /{ }^{207} \mathrm{~Pb}$ anthropogenic)].

The geogenic $\mathrm{Pb}$ can be considered the one in the lowest soil layers (Saether et al., 2011). Accordingly, the isotopic ratio of ${ }^{206} \mathrm{~Pb} /{ }^{207} \mathrm{~Pb}$ in the $40-80 \mathrm{~cm}$ layer in the fir soil represented the ratio of the geogenic $\mathrm{Pb}$.

The average value of ${ }^{206} \mathrm{~Pb} /{ }^{207} \mathrm{~Pb}(1.13)$ in the European atmosphere (Saether et al., 2011) was used as the isotopic ratio of the anthropogenic $\mathrm{Pb}$.

\section{Results and Discussion}

Concentrations of heavy metals in remote ecosystems can be used to delineate the levels of pollution or those of normal concentrations. Normal concentrations are usually considered those of remote from pollution sources ecosystems although in the past there had been problems with atmospheric metal transport. For this reason, examining the past from literature and comparison with current data is another useful procedure. 


\subsection{Hydrological cycle}

In the second hydrological year, the concentrations of all metals in bulk and throughfall deposition (Table 1) were higher than those in the first year (with the exception of $\mathrm{Cd}$, which had identical concentrations in throughfall in both years). It can be assumed that some dry deposition of metals could have taken place in the second year

In an early work, Heinrichs and Mayer, (1977) determined the average concentrations of $\mathrm{Cd}, \mathrm{Pb}, \mathrm{Cr}$ and $\mathrm{Ni}$ in the hydrological cycle of Norway spruce (Picea abies L. Karst) in the Solling Mountains in central Germany. The concentrations found in bulk deposition were $1.2 \mu \mathrm{g} \mathrm{L}^{-1}$ for $\mathrm{Cd}, 2.1 \mu \mathrm{g} \mathrm{L}^{-1}$ for $\mathrm{Cr}, 38 \mu \mathrm{g} \mathrm{L}^{-1}$ for Pb and $1.4 \mu \mathrm{g} \mathrm{L}^{-1}$ for Ni. For throughfall the concentrations for the same metals were $3.3 \mu \mathrm{g} \mathrm{L}^{-1}$ for $\mathrm{Cd}, 99 \mu \mathrm{g} \mathrm{L}^{-1}$ for $\mathrm{Pb}, 2.9 \mu \mathrm{g} \mathrm{L}^{-1}$ for $\mathrm{Cr}$ and $9.0 \mu \mathrm{g}$ $\mathrm{L}^{-1}$ for $\mathrm{Ni}$. In a later study also in Germany in the Fichtelgebirge mountains dominated by Norway spruce forests Huang et al., (2011) found median values for bulk deposition $0.03 \mu \mathrm{g} \mathrm{L}{ }^{-1}$ for $\mathrm{Cd}, 0.05 \mu \mathrm{g} \mathrm{L^{-1 }}$ for $\mathrm{Cr}$ and $0.48 \mu \mathrm{g}$ $\mathrm{L}^{-1}$ for $\mathrm{Ni}$, whereas in throughfall the median values for the same metals were $0.09 \mu \mathrm{g} \mathrm{L}^{-1}, 0.24 \mu \mathrm{g} \mathrm{L}^{-1}$ and $1.02 \mu \mathrm{g} \mathrm{L}^{-1}$, respectively. The concentrations of $\mathrm{Pb}$ are missing from the last work. Itoh et al. (2006) found $\mathrm{Pb}$ concentrations in three rural forests in Japan ranging from $0.66 \mu \mathrm{g} \mathrm{L}^{-1}$ to 1.73

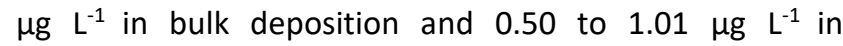
throughfall. The concentrations of As was not examined. It is obvious that the metal concentrations in the study of Heinrichs and Mayer, (1977) were far higher than those in our work but even in the more recent papers, the metal concentrations found were either equal or higher.

\subsection{Litterfall}

The rest litterfall, i.e. mosses and lichens together, insect frass and pollen had the highest concentrations with the exception of $\mathrm{Pb}$ and $\mathrm{Ni}$, which also had high values in the twigs (Table 2) just like their respective concentrations in the twigs of standing biomass. Insect frass originated mainly from Choristoneura murinana, a needle eating moth from the Tortricidae family, which is always present in this area. Pollen production was profuse in the second hydrological year. Mosses and lichens often serve as an indication of heavy metal pollution. In a mosses survey in Germany Pesch et al., (2008) found much lower concentrations in all the metals of our work (with the exception of $\mathrm{Pb}$, which were similar). The heavy metal concentrations in lichens vary extremely. Nimis et al. (2000) found great ranges in all the metals of our work in the lichen Xanthoria parietina in NE Italy. In this study, there was no separation of lichens and mosses so the origin of metals cannot easily be concluded. That is a stimulus for further research. The cone scales is wooden tissue and apart from $\mathrm{Ni}$ all the metals had low concentration. The sperms and its wings do not have a high surface and apart from $\mathrm{Ni}$ the metal concentration was low. That can be an evidence of internal translocation of $\mathrm{Ni}$ in all plant tissues. It is interesting that frass and pollen had a high metal concentration. Probably this is due to their large surface. In any case, it is a proof that metals are deposited through the atmosphere.

Table 2. Concentrations $\left(\mathrm{mg} \mathrm{kg}^{-1}\right)$ of heavy metals in the various components of litterfall in the two hydrological years

\begin{tabular}{|c|c|c|c|c|c|}
\hline & & 2012-2013 & & & \\
\hline Needles & As & $\mathrm{Cd}$ & $\mathrm{Cr}$ & $\mathrm{Ni}$ & $\mathrm{Pb}$ \\
\hline Mean & 0.507 & 0.102 & 1.08 & 3.30 & 2.34 \\
\hline Range & $(0.140-1.37)$ & $(0.06-0.142)$ & $(0.62-2.05)$ & (3.17-4.55) & $(1.00-3.64)$ \\
\hline Twigs & 0.412 & 0.303 & 1.87 & 4.42 & 5.07 \\
\hline Frass & 0.602 & 0.174 & 2.51 & 4.32 & 3.44 \\
\hline Cone scales & 0.027 & 0.040 & 0.252 & 3.08 & 0.33 \\
\hline \multirow[t]{2}{*}{ Rest } & 0.781 & 0.250 & 3.11 & 6.69 & 5.27 \\
\hline & & 2013-2014 & & & \\
\hline Needles & As & $\mathrm{Cd}$ & $\mathrm{Cr}$ & $\mathrm{Ni}$ & $\mathrm{Pb}$ \\
\hline Mean & 0.200 & 0.100 & 0.902 & 3.328 & 1.84 \\
\hline Range & $(0.154-0.287)$ & $(0.062-0.149)$ & $(0.668-1.24)$ & $(2.79-3.86)$ & $(0.97-2.72)$ \\
\hline Twigs & 0.353 & 0.308 & 1.85 & 3.97 & 7.42 \\
\hline Frass and dust & 0.678 & 0.259 & 3.34 & 5.85 & 6.34 \\
\hline Cone scales & 0.029 & 0.052 & 0.144 & 2.45 & 0.607 \\
\hline Sperms & 0.135 & 0.098 & 1.00 & 5.21 & 0.817 \\
\hline Pollen & 0.658 & 0.230 & 3.70 & 5.43 & 4.73 \\
\hline Rest & 0.795 & 0.261 & 3.98 & 7.61 & 7.41 \\
\hline
\end{tabular}

Nearly all studies on heavy metals in litterfall have dealt with fluxes rather than concentrations. The only works in literature so far that have met this objective, are those of Kapusta et al., (2003) referring to leaves litterfall in mixed forest ecosystems in Cracow, Poland and Huang et al.,
(2011) to litterfall of Picea abies in Germany. Kapusta et al. (2003) found higher concentrations of $\mathrm{Pb}$ and $\mathrm{Cd}$ than those in the needles of fir in our work. Only in high distances from Cracow the metal concentrations were similar to our results. Huang et al., (2011) found almost 
identical concentrations of $\mathrm{Cd}\left(0.10 \mathrm{mg} \mathrm{kg}^{-1}\right)$, and lower concentrations of $\mathrm{Cr}\left(0.62 \mathrm{mg} \mathrm{kg}^{-1}\right)$ and $\mathrm{Ni}\left(1.70 \mathrm{mg} \mathrm{kg}^{-1}\right)$ with regard to our results.

\subsection{Standing tree}

When comparing heavy metal concentrations in the various compartments of a coniferous forest it is useful to have the concentrations in new and older parts in the standing tree. Nutrients, in conifers, move from old needles to younger ones during senescence (Ranger et al., 1997).
Therefore, metals assuming a physiological role are expected to have lower concentrations in older needles. If, however, needles accumulate metals due to atmospheric deposition, the opposite can happen. Sometimes both processes take place, i.e. metals have an internal circulation and at the same time, metals deposited from the atmosphere accumulate in older plant parts. As a result, the outcome depends on which rate is higher. In our work, all metals had higher concentrations in older needles than the young ones with the exception of Ni (Table 3).

Table 3. Concentrations ( $\mathrm{mg} \mathrm{kg}^{-1}$ ) of heavy metals in the various compartments of the standing fir trees

\begin{tabular}{lccccc}
\hline Compartment & $\mathbf{A s}$ & $\mathbf{C d}$ & $\mathbf{C r}$ & $\mathbf{N i}$ & $\mathbf{P b}$ \\
\hline Bark & $<0.01$ & 0.162 & $<0.01$ & 0.501 & 0.189 \\
\hline Trunk wood & $<0.01$ & 0.055 & $<0.01$ & 0.277 & 0.040 \\
\hline Current year twigs & $<0.01$ & 0.212 & 0.119 & 5.37 & 1.36 \\
\hline Last year twigs & 0.066 & 0.411 & 0.300 & 4.25 & 2.49 \\
\hline Branches & $<0.01$ & 0.153 & $<0.01$ & 0.952 & 0.117 \\
\hline Current year needles & 0.026 & 0.033 & 0.120 & 3.81 & 0.612 \\
\hline Second year needles & 0.042 & 0.037 & 0.229 & 2.53 & 1.56 \\
\hline Older needles & 0.117 & 0.063 & 0.420 & 2.90 & 3.62 \\
\hline
\end{tabular}

Lower concentrations of $\mathrm{Ni}$ in current needles than in older ones were also found by Nikonov et al., (2001) in Scotch pines in Russia. The same concentration pattern was observed with the twigs of current and second year. Current year and second year twigs are those on which current and second year needles are attached. It is interesting that $\mathrm{Ni}$ also had higher concentrations in the younger twigs than the older ones. It can be concluded that an internal circulation takes place for this metal. In all compartments of the standing trees the order of concentrations was $\mathrm{Ni}>\mathrm{Pb}>\mathrm{Cr}>\mathrm{Cd}>$ As. With respect to the metals in our work, Gandois et al., (2010) found the same concentration order for $\mathrm{Ni}, \mathrm{Pb}$ and $\mathrm{Cd}$ in standing trees needles (mixed ages) of silver fir with the exception of trunk wood and branches where $\mathrm{Pb}$ had a higher concentration than $\mathrm{Ni}$. In terms of the metals concentration magnitude in needles, results vary in literature. Gandois et al., (2010) found similar concentrations with our work in needles for $\mathrm{Cd}(0.08$ $\left.\mathrm{mg} \mathrm{kg}^{-1}\right), \mathrm{Ni}\left(2.75 \mathrm{mg} \mathrm{kg}^{-1}\right)$, but lower concentrations of $\mathrm{Pb}$ $\left(0.33 \mathrm{mg} \mathrm{kg}^{-1}\right)$. In second year needles of Pinus masoniana, Kuang et al. (2007) found higher concentrations of $\mathrm{Cr}$ $\left(0.97 \mathrm{mg} \mathrm{kg}^{-1}\right)$, higher concentrations of $\mathrm{Cd}\left(0.26 \mathrm{mg} \mathrm{kg}^{-1}\right)$, similar concentrations of $\mathrm{Pb}\left(1.39 \mathrm{mg} \mathrm{kg}^{-1}\right)$ and lower concentrations of $\mathrm{Ni}\left(0.46 \mathrm{mg} \mathrm{kg}^{-1}\right)$. In mixed (in terms of age) needles of Picea abies, Mankovska (1997) found similar concentrations of $\mathrm{Pb}\left(1.73 \mathrm{mg} \mathrm{kg}^{-1}\right)$ and $\mathrm{Ni}(2.60 \mathrm{mg}$ $\left.\mathrm{kg}^{-1}\right)$ and higher concentrations of $\mathrm{Cd}\left(0.19 \mathrm{mg} \mathrm{kg}^{-1}\right), \mathrm{Cr}$ $\left(0.68 \mathrm{mg} \mathrm{kg}^{-1}\right)$ and As (1.41 $\left.\mathrm{mg} \mathrm{kg}^{-1}\right)$. Wyttenbach et al., (1996) found lower concentrations of As than those in our work in the needles of Picea abies in five age classes of remote forests in Switzerland (0.008-0.025 mg kg-1). However, the same authors found higher concentrations of As in current year needles of Picea abies and Abies alba in the Black Forest in Germany $\left(0.06-0.08 \mathrm{mg} \mathrm{kg}^{-1}\right)$.

$\mathrm{Ni}$ also had the highest concentration in the trunk wood, whereas all the other metals had very low ones (less than
5000 fold with regard to $\mathrm{Ni}$ ). With the hypothesis that trunk wood accumulates elements mainly from the soil and its metal concentration does not reflect the atmospheric pollution (Rossini Oliva and Mingorance, 2006), it can be inferred there is a substantial Ni take up from the soil. Nygård et al., (2012) argued that anthropogenic input is less important for $\mathrm{Ni}$ and $\mathrm{Cr}$ than $\mathrm{Pb}$ and $\mathrm{As}$. However, in our work the concentration of $\mathrm{Cr}$ in the older needles was higher than that in the new ones. Therefore, some deposition input of $\mathrm{Cr}$ had taken place in the fir forest. The second metal in concentration in wood tissue was $\mathrm{Cd}$. Although $\mathrm{Cd}$ has no known biological role, $\mathrm{Cd}$ uptake by living cells via essential cation routes is possible (Clemens, 2006). In the stem wood of a sugar maple (Acer sacharum) forest, Morrison and Hogan (1986) also found higher concentrations of $\mathrm{Ni}\left(0.5 \mathrm{mg} \mathrm{kg}^{-1}\right)$ with regard to $\mathrm{Cd}$ $\left(0.19 \mathrm{mg} \mathrm{kg}^{-1}\right)$ and $\mathrm{Pb}\left(0.3 \mathrm{mg} \mathrm{kg}^{-1}\right)$. Some researchers have used the ratio of the metal concentrations in tree bark over that in wood. If this ratio is over one, there is indication of atmospheric pollution (Rossini Oliva and Mingorance, 2006). In the fir stand $\mathrm{Cd}, \mathrm{Ni}$ and $\mathrm{Pb}$ had a ratio over one, whereas $\mathrm{As}$ and $\mathrm{Cr}$ had no detectable concentrations in both trunk and wood. These results, however, have to be interpreted with caution. Gandois et al., (2010) argue that in remote and unpolluted forests the increased metal concentrations in tree barks might be due to metal leaching from canopy and not directly from the atmosphere. The Ni concentrations in the second and older year's needles were lower than those in the first year. Assuming that the comparison of different year plant parts is the best method to assess metal accumulation, the bark over wood tissue method is questionable.

\subsection{Ground vegetation}

The concentrations of metals in the ground vegetation were low (Table 4). These plants are annual, and their metal concentration is mainly associated with uptake and deposition in one year. An exception was $\mathrm{Cd}, \mathrm{Cr}$ and $\mathrm{Ni}$ 
concentrations in ferns, which were rather high in comparison with the concentrations in the standing trees. In comparison with herbs and grasses, ferns have an extensive rooting system and the most probable cause is the uptake through soil. So far, there has been only one work by Martin et al. (1982) concerning heavy metal concentrations in the ground vegetation in forests.
Although the forest was contaminated deciduous woodland, the authors found high concentrations of $\mathrm{Cd}$ in ground vegetation and especially in ferns in comparison with $\mathrm{Pb}$ (the other metals cited in our work were not examined). Maybe ferns can serve as an index for $\mathrm{Cd}$ uptake.

Table 4. Concentrations ( $\mathrm{mg} \mathrm{kg-1)}$ of heavy metals in the various plant groups of ground vegetation

\begin{tabular}{lccccc}
\hline & As & Cd & Cr & Ni & Pb \\
\hline Herbs & 0.049 & 0.076 & 1.33 & 3.00 & 0.651 \\
Ferns & 0.001 & 0.262 & 1.23 & 7.26 & 0.122 \\
Grasses & 0.001 & 0.004 & 0.010 & 0.364 & 0.019 \\
\hline
\end{tabular}

\subsection{Soils}

The coefficient of variation was highest in the $L$ horizon for all metals (Table 5). This can be attributed to the variation of absorbing capacity of the L layer, as decomposition differs in space, variation in throughfall deposition and plant (including ground vegetation) take up of metals. The heavy metal content of the soil depends on several factors. The parent material, the $\mathrm{pH}$, the organic matter, the clay content and cation exchange capacity. The parent material of the soil in our work is flysch, which is a sedimentary marine formation. This type of flysch alternates sandy and clay content. In general, the clayey sediments have higher concentrations of heavy metals than sandstones (Chimidorzhieva et al., 2012). The $\mathrm{pH}$ of the soil is slightly acidic as depth increases (Table 6) and the organic matter becomes lower with depth. These two factors contribute to lower metal concentrations with depth, but the relatively high clay content counteracts this trend. Another important factor when comparing heavy metal concentrations of various soils is the method of digestion. The use of HF acid brings about complete dissolution of the silicate minerals, whereas the other concentrated acids do not have that ability. Consequently, the rest of the acids will result in lower concentrations. Nasseem, (1980) found that total concentrations of $\mathrm{Cu}$ and $\mathrm{Zn}$ in alluvial and calcareous soils using the HF digests were approximately $20 \%$ higher than the corresponding ones estimated using aqua regia digests. The use of X-ray fluorescence and fusion with alkali carbonates or metaborate salts are also supposed to give total concentrations. In any case, the method must be mentioned.

Table 5. Concentrations $\left(\mathrm{mg} \mathrm{kg}^{-1}\right)$ of heavy metals in soil layers of the fir plot

\begin{tabular}{|c|c|c|c|c|c|}
\hline Layer & As & Cd & $\mathrm{Cr}$ & $\mathbf{N i}$ & $\mathrm{Pb}$ \\
\hline \multirow[t]{2}{*}{$\mathrm{L}$} & 0.639 & 0.077 & 3.00 & 7.32 & 4.60 \\
\hline & $(113)^{*}$ & (57) & (36) & (91) & (115) \\
\hline \multirow[t]{2}{*}{$\mathrm{FH}$} & 5.58 & 0.591 & 78.1 & 43.9 & 38.6 \\
\hline & (12) & $(15)$ & (12.2) & (10.4) & (7.4) \\
\hline \multirow[t]{2}{*}{$0-10 \mathrm{~cm}$} & 8.02 & 0.313 & 125 & 67.6 & 22.3 \\
\hline & (3.4) & $(4.5)$ & (3.2) & $(4.2)$ & (6.7) \\
\hline \multirow[t]{2}{*}{$10-20 \mathrm{~cm}$} & 8.55 & 0.264 & 126 & 65.1 & 20.6 \\
\hline & $(1.7)$ & $(12)$ & (2.5) & (6.4) & (2.9) \\
\hline \multirow[t]{2}{*}{$20-40 \mathrm{~cm}$} & 9.13 & 0.201 & 128 & 72.1 & 16.5 \\
\hline & $(4.0)$ & $(11)$ & $(0.97)$ & $(5.0)$ & (13) \\
\hline \multirow[t]{2}{*}{$40-80 \mathrm{~cm}$} & 9.47 & 0.176 & 135 & 73.4 & 14.5 \\
\hline & $(5.2)$ & $(18)$ & $(1.6)$ & $(8.0)$ & $(12)$ \\
\hline
\end{tabular}

\section{*Coefficient of variation}

The highest concentrations for $\mathrm{Pb}$ and $\mathrm{Cd}$ were found in the FH layer (Table 5), whereas for the other metals the mineral layers had the highest concentrations. Pb forms covalent bonds with organic matter and $\mathrm{Cd}$ is mainly bound in the exchangeable form. The high magnitude of both organic $C$ and C.E.C. in the FH layer is an explanation for that. $\mathrm{Cd}$ is not enriched in the mineral layers as after the $\mathrm{FH}$ horizon its concentrations decrease (Table 5). The proportion of $\mathrm{Cd}$ transported in soils is larger than the other metals
(Bergvist, 1987). It is probable that the $\mathrm{pH}$ values in our soils were not low enough to promote $\mathrm{Cd}$ migration, as it is known that low pH significantly increases $\mathrm{Cd}$ solubility (Christensen, 1984). The highest concentration in the $\mathrm{FH}$ layers and the mineral layers was that of $\mathrm{Cr}$ followed by $\mathrm{Ni}$. The metal concentrations in the mineral soil followed the order $\mathrm{Cr}>\mathrm{Ni}>\mathrm{Pb}>\mathrm{As}>\mathrm{Cd}$. The same order was found by Blaser et al., (2000) for Swiss forest soils using X-ray fluorescence analysis (the authors did not include $\mathrm{Cd}$ in 
their study). In addition, the ranges of metal concentrations in soil layers found by Blaser et al., (2000) were quite similar with those found in the present work. Lower concentrations for $\mathrm{Cd}, \mathrm{Ni}$ and $\mathrm{Pd}$ were found by Gandoi et al. (2010) who used HF to digest samples of forest soils in northeastern France. However, those soils had a sandy texture. Hernandez et al. (2003) using HF acid to digest various forest soils in France found the concentration order $\mathrm{Cr}>\mathrm{Pb}>\mathrm{Ni}>\mathrm{Cd}$ apart from some soils where the $\mathrm{Ni}$ concentrations were higher than $\mathrm{Pb}$. They also found (like in our work) increasing concentrations with depth of $\mathrm{Cr}$ and $\mathrm{Ni}$ and ascribed it to weathering and/or leaching within the soil profile. Vanemechen et al., (1997) quoted the concentrations and ranges of some heavy metals in European forest soils determined by digestion with aqua regia. The metals $\mathrm{Cr}, \mathrm{Ni}, \mathrm{Pb} \mathrm{Cd}$ were included. The concentration ranges found in the soils, in $\mathrm{mg} \mathrm{kg}^{-1}$, were for $\mathrm{Cr}$ 50-100, for Ni 30-60 for $\mathrm{Cd}$ 0.8-1.5 and for $\mathrm{Pb}$ 50-100. Nevertheless, the concentrations were lower than the values found in this work with the exception of $\mathrm{Cr}$. Hernandez et al., (2003) also found high concentrations of $\mathrm{Cr}$ (similar to our work) in forest soils (using HF acid).

Table 6. Selected properties of the soil in the fir stand. Organic $C$ and clay are expressed in percentages (\%) and C.E.C. in cmolsc per kg of soil.

\begin{tabular}{|c|c|c|c|c|}
\hline Layer & pH & Org. C & C.E.C. & Clay \\
\hline \multirow[t]{2}{*}{$\mathrm{FH}$} & 6.48 & 23.0 & 57.8 & \\
\hline & $(0.24)^{*}$ & (13) & (9.5) & \\
\hline \multirow[t]{2}{*}{$0-10 \mathrm{~cm}$} & 6.07 & 5.12 & 37.3 & 27.2 \\
\hline & (1.99) & (20.0) & (14.8) & $(2.02)$ \\
\hline \multirow[t]{2}{*}{$10-20 \mathrm{~cm}$} & 5.77 & 3.36 & 23.6 & 31.2 \\
\hline & (3.15) & (10.3) & (12.9) & (2.1) \\
\hline \multirow[t]{2}{*}{$20-40 \mathrm{~cm}$} & 5.54 & 2.75 & 17.2 & 33.0 \\
\hline & (1.18) & (3.51) & (5.3) & (6.7) \\
\hline \multirow[t]{2}{*}{$40-80 \mathrm{~cm}$} & 5.32 & 1.53 & 11.3 & 34.9 \\
\hline & (1.49) & (19.3) & (5.3) & $(14.1)$ \\
\hline
\end{tabular}

\section{*Coefficient of variation}

As is probably the least studied metal in forest soils despite its toxicity. Hansen et al., (2001) using hot $\mathrm{HNO}_{3}$ to digest soil samples from Chinese forests found slightly lower values than those in our work with the exception of some extreme high values in one soil type although the authors claimed that the soils were in unpolluted areas. Nygård et al., (2012) also used hot $\mathrm{HNO}_{3}$ to digest soil organic horizons from Norwegian forests and found a lower average value of As concentration than that in our work although there was a large range of values in their results.

The heavy metal concentrations in the lowest soil layers can be used to represent the natural geological background. This approach was used by Blaser et al., (2000). If the depth $40-80 \mathrm{~cm}$ reflects the lithogenic concentrations, there was enrichment only for $\mathrm{Pb}$ and $\mathrm{Cd}$ (Table 5). Therefore, it can be assumed that both of those metals in the other soil layers were derived from anthropogenic origin. However, as mentioned, As and $\mathrm{Cr}$ concentrations were enriched in older fir needles. It can be concluded that higher metal concentrations in deeper soil layers cannot be the only criterion to assess anthropogenic impact.

\subsection{Percentage of anthropogenic $\mathrm{Pb}$ in soils}

The method of determination the percentages of anthropogenic $\mathrm{Pb}$ in soils is based on the stable isotopic ratio that $\mathrm{Pb}$ had in petrol (related to its mineral origin) and its relation to that of geogenic origin which also is stable depending of course on the rock type (Sturgies and Barrie, 1987). Among all isotopes, the ${ }^{206} \mathrm{~Pb} /{ }^{207} \mathrm{~Pb}$ ratio is used widely. Not all the quantity of anthropogenic $\mathrm{Pb}$ found in the environment comes from petrol used in the past decades. Shotyk et al., (2004) found that $50-75 \%$ of anthropogenic $\mathrm{Pb}$ was preindustrial $\mathrm{Pb}$. At a local scale, the introduction of $\mathrm{Pb}$ was done about 1000 years ago when the $\mathrm{Cu}$ mining became widespread (Mighall et al., 2009). There has been no information on the preindustrial $\mathrm{Pb}$ use in the area of research. Therefore, the use of ${ }^{206} \mathrm{~Pb} /{ }^{207} \mathrm{~Pb}$ ratio was taken equal to the average value, i.e. 1.13 found in the European atmosphere (Saether et al., 2011).

As mentioned for total dissolution of soil minerals by strong acids with regard to heavy meal concentrations, the same remark has to be made for the $\mathrm{Pb}$ isotopic ratios. The total dissolution involving $\mathrm{HF}$ gives higher values of ${ }^{206} \mathrm{~Pb} /{ }^{207} \mathrm{~Pb}$ ratios. The reason is the existence of resistant minerals to weak acids like zirconium, which tend increase the ${ }^{206} \mathrm{~Pb} /{ }^{207} \mathrm{~Pb}$ ratio (Erel et al., 2004).

The values of ${ }^{206} \mathrm{~Pb} /{ }^{207} \mathrm{~Pb}$ in the various mineral soil layers (Table 7) had very low coefficients of variations, far lower than those in the $\mathrm{Pb}$ concentrations (Table 6). That means that the anthropogenic $\mathrm{Pb}$ migrated more or less uniformly down the soil profiles. All values increased with depth. Similar distributions of ${ }^{206} \mathrm{~Pb} /{ }^{207} \mathrm{~Pb}$ with depth was found by Wilke et al., (2001) and Steinnes et al., (2005) in soils under Scotch pine in forest soils in Slovakia and Norway, respectively. 
Table 7. Values of the ${ }^{206} \mathrm{~Pb} /{ }^{207} \mathrm{~Pb}$ ratios in soil layers of the fir plot and percentages of anthropogenic $\mathrm{Pb}$

\begin{tabular}{|c|c|c|}
\hline Layer & Ratios & Percentage \\
\hline $\mathrm{FH}$ & $\begin{array}{c}1.168 \\
(0.27)^{*}\end{array}$ & 41.1 \\
\hline $0-10 \mathrm{~cm}$ & $\begin{array}{l}1.185 \\
(0.10)\end{array}$ & 13.5 \\
\hline $10-20 \mathrm{~cm}$ & $\begin{array}{l}1.150 \\
(0.22)\end{array}$ & 6.25 \\
\hline $20-40 \mathrm{~cm}$ & $\begin{array}{l}1.193 \\
(0.27)\end{array}$ & 2.08 \\
\hline $40-80 \mathrm{~cm}$ & $\begin{array}{l}1.194 \\
(0.17)\end{array}$ & - \\
\hline
\end{tabular}

\section{*Coefficient of variation}

The values of ${ }^{206} \mathrm{~Pb} /{ }^{207} \mathrm{~Pb}$ in the present work ranged from 1.168 in the $\mathrm{FH}$ horizon to 1.194 in the $40-80 \mathrm{~cm}$ layer. In forest soils in Sweden the isotopic ratio range was found $1.3->2$ in the $C$ horizons, whereas in surface soils the range was 1.14-1.18 (Bindler, 2011). With regard to the percentages of anthropogenic $\mathrm{Pb}$, the values varied from $41 \%$ in the $\mathrm{FH}$ horizon to $2 \%$ in the $20-40 \mathrm{~cm}$ layers (Table 7). In comparison with values found in other forest soils, the percentages are rather low. Watmouth and Hutchinson (2004), found that approximately $60 \%$ of $\mathrm{Pb}$ in the top soil under conifers in Ontario of Canada was anthropogenic. Itoh et al., (2007) found 55\% of anthropogenic $\mathrm{Pb}$ in the forest floor under Japanese cedar $120 \mathrm{~km}$ from Tokyo. Even in pristine areas of northern Norway more than $80 \%$ of the humus layer was found to be of anthropogenic origin (Steinnes et al., 2005).

In conclusion, the soil under consideration was found to have lower percentages of anthropogenic $\mathrm{Pb}$ than the forests of industrial countries in Europe. Nevertheless, the percentage of anthropogenic $\mathrm{Pb}$ reached a value of $41 \%$ in the $\mathrm{FH}$ horizon.

\section{Conclusions}

- In comparison with the past, the metal concentrations in bulk and througfall deposition in the fir stand were found lower. Nevertheless, the metal concentrations in the second hydrological year were higher than the first one indicating atmospheric deposition.

- In litterfall, insect frass and pollen had the highest metal concentrations among all fractions. This was probably a combination of their large surface area and metal dry deposition. With regard to past information from conifers, litterfall needles had lower concentrations of $\mathrm{Pb}$ and $\mathrm{Cd}$ but higher ones of $\mathrm{Ni}$ and $\mathrm{Cr}$.

- The high concentrations of metals (with the exception of $\mathrm{Ni}$ ) in older tree parts such as needles and twigs is a strong evidence of dry deposition.
- $\quad \mathrm{Ni}$ appears to have an internal cycle in trees more intensive than the other metals. This conclusion was derived from the finding that $\mathrm{Ni}$ had the highest concentration in the trunk wood under the hypothesis of course, that trunk accumulates elements mainly from soil. Nevertheless, its high concentrations in pollen and insect frass litterfall testifies to the existence of dry deposition of this metal too.

- In the ground vegetation, ferns had higher concentrations of $\mathrm{Cd}, \mathrm{Cr}$ and $\mathrm{Ni}$ with regard to the respective concentrations in the standing trees. High concentrations of $\mathrm{Cd}$ in ferns have been reported by other authors. Probably, ferns could serve as an index for $\mathrm{Cd}$ uptake from soils.

- In soils the highest concentrations for $\mathrm{Pb}$ and $\mathrm{Cd}$ were found in the $\mathrm{FH}$ layer but the highest concentrations (in absolute magnitude) for all metals were those of $\mathrm{Cr}$ and $\mathrm{Ni}$. In the mineral layers the order of concentrations was $\mathrm{Cr}>\mathrm{Ni}>\mathrm{Pb}>\mathrm{As}>\mathrm{Cd}$. The metal enrichment in deep soil layers cannot be the only criterion to assess anthropogenic impact. The comparison of new and old plant tissues metal concentrations can also reveal information.

- The isotopic ratios of ${ }^{206} \mathrm{~Pb} /{ }^{207} \mathrm{~Pb}$ showed that although the soil in the fir stand had lower percentages of anthropogenic $\mathrm{Pb}$ than the forests of industrial countries in Europe, still an appreciable percentage (41\%) of anthropogenic $\mathrm{Pb}$ was found in the $\mathrm{FH}$ soil horizon.

\section{Acknowledgements}

The authors express their appreciation to the Ministry of Agriculture and Food, the Mistry of Environment and the European Commission, which financially sustain the Programme of "Effects of Atmospheric Pollutants on Forest Ecosystems" on the framework of which the current project was based. In addition, the authors want to express their sincere thanks to $\mathrm{Ch}$. Mitropoulou for their help with sample pretreatment and analysis 
and to the Forest Service of Karpenisi for their invaluable practical help.

\section{References}

Bache C.A., Elfving D.C. and Lisk D.J. (1992), Cadmium and lead concentration near a municipal refuse incineration, Chemosphere 24, 475-481.

Blaser P., Zimmermann S., Luster J. and Shotyk W. (2000), Critical concentrations and depletion in soils: $\mathrm{As}, \mathrm{Cr}, \mathrm{Ni}, \mathrm{Pb}$ and $\mathrm{Zn}$ in Swiss forest soil, Science of The Total Environment, 249, 257-280.

Berg B., De Santo A.V., Rutigliano F.A., Fierro A. and Ekbohn G. (2003), Limit values for plant litter decomposing in two contrasting soils-influence of litter elemental composition, Acta Oecologica, 24, 295-302.

Bergvist B. (1987), Soil solution chemistry and metal budgets of spruce forest ecosystems in S. Sweden, Water Air and Soil Pollution, 33, 131-154.

Bindler R. (2011), Contaminated lead environments of man: reviewing the lead isotopic evidence in sediments, peat, and soils for the temporal and special patterns of atmospheric lead pollution in Sweden, Environmental Geochemistry and Health, 33, 311-329.

Bringmark L., Lundin L., Augustaitis A., Beudert B., DieffenbachFries H., Dirnböck T., Grabner M.-T., Hutchins M., Kram P., Lyulko I., Ruoho-Airola T. and Vana M. (2013), Trace metal budgets for forested catchments in Europe-Pb, Cd, Cu and Zn, Water Air and Soil Pollution 224, 1502-1516.

Certini V.G., Corti G. and Ugolini F.C. (2000), Influence of soil properties on the mortality of silver fir in Tuscany, Italy, Forstwesen Cbl, 119, 323-331.

Chimitdorzhieva G.D., Nimbueva A.Z. and Bodeeva E.A. (2012), Heavy Metals (copper, lead, Nickel and Cadmium), Eurasian Soil Science, 45, 141-146.

Christensen T.H. (1984), Cadmium sorption at low concentrations: I. Effects of time, cadmium load, $\mathrm{pH}$ and calcium, Water Air and Soil Pollution, 21, 105-114.

Clemens S. (2006), Toxic metal accumulation, responses to exposure and mechanisms of tolerance in plants, Biochimie, 88, 1707-1719.

Emmanuel S. and Erel Y. (2002), Implications from concentrations and ispotopic data for $\mathrm{Pb}$ portioning processes in soils, Geochimica et Cosmochimica Acta, 14, 2517-2527.

Erel Y., Blum J.D., Roueff E. and Ganor J. (2004), Lead and strontium isotopes as monitors of experimental granitoid mineral dissolution, Geochimica et Cosmochimica Acta, 68 4649-4663.

FAO-Unesco (1988), Soil map of the world. FAO-Unesco, Rome, Italy.

Friedland A.G. and Johnson H. (1985), Lead distribution and fluxes in a high-elevation forest in Northern Vermont, Journal of Environmental Quality, 14, 332-336.

Gandois L. and Probst A. (2012), Localisation and mobility of trace metals in silver fir needles, Chemosphere 87, 204-210.

Gandois L., Nicolas M., VanderHeijden G. and Probst A. (2010), The importance of biomass net uptake for a trace metal budget in a forest stand in north-eastern France, Science of The Total Environment, 408, 5870-5877.

Hansen H., Larsen T., Seip H.M. and Voght R.D. (2001), Trace metals in forest soils at four sites in southern China, Water Air and Soil Pollution, 130, 1721-1726.
Heinrichs H. and Mayer R. (1977), Distribution and cycling of major and trace elements in two central European forest ecosystems, Journal of Environmental Quality, 4, 402-407.

Hernandez L., Probst A., Probst J.L. and Ulrich E. (2003), Heavy metal distribution in some French soils, Science of The Total Environment, 312, 195-219.

Huang J.H., llgen G. and Matzner E. (2011), Fluxes and budgets of $\mathrm{Cd}, \mathrm{Zn}, \mathrm{Cu}, \mathrm{Cr}$ and $\mathrm{Ni}$ in a remote forested catchment in Germany, Biogeochemistry, 103, 59-70.

Itoh Y., Noguchi K., Takahashi M., Okamoto T.M. and Yoshinaga S. (2007), Estimation of lead sources in a Japanese cedar ecosystem using stable isotope analysis, Applied Geochemistry, 22, 1223-1228.

Kapusta K.S., Zakrzewska M., Bajorec K. and Argasinska J.G. (2003), Input of heavy metals to the forest floor as a result of Cracow urban pollution, Environment International, 28, 691-698.

Krause G.H.M., Arndt U., Brandt C.J., Bucher J., Kenk G. and Matzner E. (1986), Forest decline in Europe: development and possible causes, Water Air and Soil Pollution, 31, 647-668.

Kuang Y.W., Wen D.Z., Zhou G.Y. and Liu S.Z. (2007), Distribution of elements in needles of Pinus massoniana (Lamb.) was uneven and affected by needle age, Environmental Pollution, 145, 730-737.

Markalas S. (1992), Site and stand factors related to mortality rate in a fir forest after a combined incidence of drought and insect attack, Forest Ecology and Management, 47, 367-374.

Martin M.H., Doncan E.M. and Coughtrey P.J. (1982), The distribution of heavy metals in a contaminated woodland ecosystem, Environmental Pollution Series B, 3, 147-157.

Mankovska B. (1998), The chemical composition of spruce and beech foliage as environmental indicator in Slovakia, Chemosphere, 36, 949-953.

Michopoulos P., Baloutsos G., Economou A., Nikolis N., Bakeas E.B. and Thomaidis N.S. (2005), Biogeochemistry of lead in an urban forest in Athens, Greece, Biogeochemistry 73, 345-357.

Mighall T.M., Timberlake S., Foster I.D., Krupp E. and Singh S. (2009), Ancient copper and lead pollution records from a raised bog complex in central Wales, UK, Journal of Archaeological Science, 36, 1504-1515.

Mingorance M.D., Valdez B. and Oliva S.R. (2007), Strategies of heavy metal uptake by plants growing under industrial emissions, Environment International, 33, 514-520.

Morrison I.K. and Hogan G.D. (1986), Trace element distribution within the tree phytomass and forest floor of a tolerant hardwood stand, Algoma, Ontario, Water Air and Soil Pollution, 31, 493-500.

Nasseem M.G. (1980), Determination of total copper and zinc contents of Egyptian soils using three different methods, Plant and Soil, 55, 327-331.

Nikonov V., Goryinova V. and Lukina N. (2001), Ni and Cu migration and accumulation in forest ecosystems on the Kola Peninsula, Chemosphere, 42, 93-100.

Nimis P.L., Lazzarin G., Lazzarin A. and Skert N. (2000), Biomonitoring of trace elements in Veneto (NE Italy), Science of The Total Environment, 255, 97-111.

Nygård T., Steinnes E. and Rayaset O. (2012), Distribution of 32 elements in organic surface soils: Contributions from 
atmospheric transport of pollutants and natural sources, Water Air and Soil Pollution, 223, 699-713.

Pesch R., Schröder W. and Dieffenbach-Fries H. (2008), Improving the design of environmental monitoring networks. Case study on the heavy metals in mosses survey in Germany, Ecological Information, 3, 111-121.

Pietrzykoski M., Socha J. and van Doorn N.S. (2014), Linking heavy metal bioavailability ( $\mathrm{Cd}, \mathrm{Cu}, \mathrm{Zn}$ and $\mathrm{Pb}$ ) in Scots pine needles to soil properties in reclaimed mine areas, Science of The Total Environment, 470-471, 501-510.

Raftoyannis Y., Spanos I. and Radoglou K. (2008), The decline of Greek fir (Abies cephalonica Loudon): Relationships with root condition, Plant Biosystems, 142, 386-390.

Ranger J., Marques R. and Colin-Belgrand M. (1997), Nutrient dynamics during the development of Douglas fir (Pseodotsuga menziesii Mirb) sand, Acta Oecologica 18, 73-90.

Rodrigo A., Avila A. and Gómez-Blea A. (1999), Trace metal contents in Parmeia caperata (L.) Ach. compared to bulk deposition, throughfall and leaf-wash fluxes in two holm oak forests in Montseny (NE Spain), Atmospheric Environment, 33, 359-367.

Rosssini Oliva S. and Mingorance M.D., (2006), Assessment of airborne heavy metal pollution by aboveground pant parts, Chemosphere, 65, 177-182.

Saether O.M., Aberg G. and Steinnes E. (2011), Lead isotope distribution in podzolic soil profiles on different types of bedrock in a formerly glaciated terrain (Oslo, Norway), Applied Geochemistry 26, 5345-5249.

Shotyk W., Blaser P., Gruning A. and Cheburkin A.K. (2000) A new approach for quantifying cumulative, anthropogenic, atmospheric lead deposition using peat cores from bogs: $\mathrm{Pb}$ in eight Swiss peat bog profiles, Science of The Total Environment, 249, 281-295.

Steiness E. and Friedland A.J. (2005), Metal contamination of natural surface soils from long range atmospheric transport: existing and missing knowledge, Environmental Reviews, 14, 169-186.

Steinnes E., Sjøbakk T.E., Donisa C. and Brännvall M.L. (2005), Quantification of pollutant lead in forest soils, Soil Science Society American Journal, 69, 1399-1404.

Sturges W.T. and Barrie L.A. (1987), Lead isotope ratios in the atmosphere of North America as tracers of US and Canadian emissions, Nature, 329, 144-146.

Tipping E., Lawlor A.J., Lofts S. and Shotbolt L. (2006), Simulating the long-term chemistry of an upland UK catchment: heavy metals, Environmental Pollution, 141, 139-150.

Turner R.S., Johnson A.H. and Wang D. (1985), Biogeochemistry of lead in McDonalds Branch Watershed, New Jersey Pine Barrens, Journal of Environmental Quality, 14, 305-314.

Van Hook R.I., Harris W.F. and Henderson G.S. (1977), Cadmium, lead and zinc distribution and cycling in a mixed deciduous forest, Ambio, 6, 281-286.

Vanmechelen L., Groenmans R. and van Ranst E. (1997), Forest soil condition in Europe. Results of a large-scale survey. Technical report, EC, UN/ECE, Ministry of the Flemish Community, Brussels, Geneva.

Watmough S.A. and Hutchinson T.C. (2004), The quantification and distribution of pollution $\mathrm{Pb}$ at a woodland in rural southcentral Ontario, Canada, Environmental Pollution, 128, 419-428.
Watmough S.A. and Dillon P.J. (2007), Lead biogeochemistry in a central Ontario forested watershed, Biogeochemistry 84, 143159.

Wilke W., Krauss M., Zech J. and Kobza W. (2001), Quantification of anthropogenic lead in Slovak forest and arable soils along a deposition gradient with stable lead isotope ratios, Journal of Plant Nutrition and Soil Science, 164, 303-307.

Wyttenbach A., Bajo S., Furrer V., Langenauer M. and Tobler L. (1996), The accumulation of arsenic, bromine and iodine in needles of Norway spruce (Picea abies (L.) Karst.) at sites with low pollution, Water Air and Soil Pollution, 94, 417-430.

Zöttl H.W. (1985), Heavy metals levels and cycling in forest ecosystems, Experientia, 41, 1104-1113. 